\title{
Third Census of Seabird Populations of the Gaspé Peninsula, Québec, 2002
}

\author{
Richard CotTer and Jean-FrançoIs RaIL
}

Canadian Wildlife Service, P. O. Box 10100, Ste-Foy, Québec G1V 4H5 Canada

Cotter, Richard, and Jean-François Rail. 2007. Third census of seabird populations of the Gaspé Peninsula, Québec, 2002. Canadian Field-Naturalist 121(3): 274-286.

In the tradition of the quinquennial census of seabirds in the Migratory Bird Sanctuaries along Québec's North Shore, which began in 1925, this paper presents the results of the first three seabird censuses of the Gaspé Peninsula conducted in 1979, 1989, and 2002, with an emphasis on the third census and on changes in seabird populations that occurred between the second and third censuses. In 1979 the population of seabirds was estimated at 134163 birds, and this increased $72 \%$ to 231186 birds in 1989. The upward trend in population continued in the 1990s but less sharply. The 2002 census recorded 279276 birds, a $21 \%$ increase over the second census. The seabird community of the Gaspé Peninsula comprises 14 species. In each of the three censuses, three species accounted for over $75 \%$ of the total seabird population: Northern Gannet, Black-legged Kittiwake, and Common Murre. Between 1989 and 2002, Common Eider, Northern Gannet, Great Cormorant, Ring-billed Gull, Razorbill, and Black Guillemot increased in numbers, whereas Herring Gull, Black-legged Kittiwake, and Common Tern all suffered declines. Populations for Double-crested Cormorant, Great Black-backed Gull, and Common Murre all remained stable. Very small populations ( $<25$ birds) of Leach's Storm-Petrel and Atlantic Puffin have been recorded during the censuses at only one location, Bonaventure Island. In the 2002 census there were no petrels observed, neither of adults nor of active burrows.

À l'instar des inventaires quinquennaux des oiseaux marins dans les refuges d'oiseaux migrateurs de la Côte-Nord, entrepris en 1925, cet article présente les résultats des trois premiers inventaires complets des oiseaux de mer nicheurs en Gaspésie, menés en 1979, 1989 et 2002. Une attention particulière est mise sur le statut des espèces d'après le troisième inventaire, et sur les tendances des populations entre les deux derniers inventaires. En 1979, le nombre d'oiseaux marins nicheur était évalué à 134163 oiseaux, puis ce total a augmenté de $72 \%$ pour atteindre 231186 oiseaux en 1989. Cette tendance à la hausse a continué dans les années 90, mais moins rapidement. En 2002 l'estimation était de 279276 oiseaux, soit une hausse de $21 \%$ par rapport au deuxième inventaire. La communauté d'oiseaux de mer de la Gaspésie est formée de 14 espèces nicheuses. Dans chacun des trois inventaires, trois espèces représentaient plus de $75 \%$ de la population totale des oiseaux marins: le Fou de Bassan, la Mouette tridactyle, et le Guillemot marmette. Entre 1989 et 2002, l'Eider à duvet, le Fou de Bassan, le Grand Cormoran, le Goéland à bec cerclé, le Petit Pingouin et le Guillemot à miroir ont vu leurs nombres croître, tandis que le Goéland argenté, la Mouette tridactyle et la Sterne pierregarin subissaient des déclins. Les populations de Cormoran à aigrettes, Goéland marin et Guillemot marmette sont demeurées stables. Les petites populations $(<25$ oiseaux $)$ d'Océanite cul-blanc et de Macareux moine n'ont été vues durant ces inventaires qu'à l'île Bonaventure. Cependant, aucun nid actif d'océanite ne fut localisé à cet endroit en 2002.

Key Words: Seabirds, populations, larids, alcids, Gaspé Peninsula, Bonaventure Island, Forillon National Park, Québec.

Seabird populations of the Gaspé Peninsula have long been well known due to two very popular summer tourist destinations: Forillon National Park of Canada and the town of Percé. At Percé boat tours are offered around Rocher Percé and Bonaventure Island, which together form a provincial park as well as a federal Migratory Bird Sanctuary. The most striking features of these sites are the high vertical cliffs holding large Black-legged Kittiwake colonies and the spectacular Northern Gannet colony on Bonaventure Island. (Scientific names are in Table 1.) With eight breeding seabird species numbering more than 100000 pairs in 2002, Bonaventure Island is undoubtedly the most important seabird colony in the area; nevertheless, the smaller mainland cliffs, together with a few islands and sand bars distributed around the peninsula, are also home to numerous colonies of cormorants, gulls, guillemots and Razorbills.

Chapdelaine and Brousseau (1992) published the first account the distribution and abundance of all seabird species breeding along the entire Gaspé Peninsula in eastern Québec. They presented the results of the first systematic censuses of seabirds for the region-in 1979 and 10 years later in 1989-as well as changes in populations and distribution for each species. After an interval of 13 years, in 2002 the Canadian Wildlife Service conducted a third seabird census. The objective of this paper is to present the results of all three censuses, but with an emphasis on describing the changes in seabird populations and distribution that occurred between 1989 and 2002. This paper therefore complements and updates Chapdelaine and Brousseau (1992) who discussed the changes that occurred between 1979 and 1989 .

\section{Methods}

On the Gaspé Peninsula, seabird species (Table 1) were censused at 59 breeding sites (Table 2, Figure 1) during June and early July in 1979, 1989, and 2002 by the Canadian Wildlife Service-Québec Region. There 
TABLE 1. Species names and summary of census methods used for each species in the 1979, 1989, and 2002 seabird censuses of the Gaspé Peninsula.

\begin{tabular}{|c|c|c|}
\hline English name & Scientific name & Methodology \\
\hline Common Eider & Somateria mollissima & $\begin{array}{l}\text { systematic counts of all nests, except for Îlot Mahy nord } \\
\text { where flushed females were counted }\end{array}$ \\
\hline Leach's Storm-Petrel & Oceanodroma leucorhoa & systematic counts of active burrows \\
\hline Northern Gannet & Morus bassanus & population analysis from aerial photography \\
\hline Double-crested Cormorant & Phalacrocorax auritus & $\begin{array}{l}\text { nests counted from a boat, except for the Upper Plateau } \\
\text { of Rocher Percé where nests were counted from a look } \\
\text { out point using a spotting scope }\end{array}$ \\
\hline Great Cormorant & Phalacrocorax carbo & nests counted from a boat \\
\hline Ring-billed Gull & Larus delawarensis & systematic counts of all nests \\
\hline Herring Gull & Larus argentatus & $\begin{array}{l}\text { systematic counts of nests; ratio calculated where nested } \\
\text { with Great Black-backed Gulls; counts of incubating } \\
\text { adults on cliffs made from a boat }\end{array}$ \\
\hline Great Black-backed Gull & Larus marinus & $\begin{array}{l}\text { systematic counts of nests (sometimes from boat); ratio } \\
\text { calculated where nested with Herring Gull }\end{array}$ \\
\hline Black-legged Kittiwake & Rissa tridactyla & $\begin{array}{l}\text { Bonaventure Island, Cap d'Espoir, Forillon Peninsula: } \\
\text { counts derived from photographs (taken from boat); } \\
\text { elsewhere nests were counted from a boat }\end{array}$ \\
\hline Common Tern & Sterna hirundo & systematic counts of all nests \\
\hline Common Murre & Uria aalge & $\begin{array}{l}\text { counts of birds at colonies on cliffs; used a conversion } \\
\text { factor of } 0.76 \text { pair/bird observed }\end{array}$ \\
\hline Razorbill & Alca torda & counts of birds at colonies on cliffs \\
\hline Black Guillemot & Cepphus grylle & $\begin{array}{l}\text { counts of birds at colonies on cliffs and on the water; } \\
\text { used Cairns (1979) conversion factor to estimate the } \\
\text { number of breeding pairs }\end{array}$ \\
\hline Atlantic Puffin & Fratercula arctica & counts of adult birds \\
\hline
\end{tabular}

were three exceptions with respect to the year of the census, and these were: Black Guillemots at Cloridorme to Marsoui were counted in 1980 instead of in 1979, Common Eiders at Pointe de Sandy Beach were counted in 2003 instead of in 2002, and Northern Gannets at Bonaventure Island were counted in 2004 instead of in 2002. The census techniques employed varied among species and colonies but were consistent for each colony among the three censuses (i.e., 1979, 1989, and 2002). A detailed explanation of the techniques used in 1979 and 1989 can be found in Chapdelaine and Brousseau (1992); with few exceptions the same methods were used in 2002. A brief description of the techniques used in 2002 for each species is presented in Table 1. Certain species, such as Black Guillemots and Herring and Great Blackbacked gulls, nest in colonies as well as solitary pairs or in very small groups. As such, for these species the distribution and colony size data may pertain to a section of shoreline rather than a discrete colony. At colonies where a species was believed to have been present but there are no population estimate available, a " + " is indicated in the corresponding table. To examine changes in population sizes between the three censuses, that is from 1979 to 1989 and from 1989 to 2002, the compound annual growth rate (CAGR) was calculated for each species using the formula: CAGR $=\left(((\mathrm{N}(\mathrm{t})-\mathrm{N}(0)) / \mathrm{N}(0)+1)^{1 / \mathrm{t}}\right)-1$ where $N(t)=$ population size at time $t, N(0)=$ population size at time 0 and $\mathrm{t}=$ number of years between two censuses.

\section{Results}

During the surveys in 1979, 1989, and 2002, a total of 14 species of seabirds was recorded at 59 breeding sites (colonies and/or shoreline sectors) around the Gaspé Peninsula (Tables 1, 2). Twelve species were observed in all three censuses, with the remaining two absent in one of the census years (Tables 3-8). In 2002, 13 species were observed, with only the Leach's StormPetrel not recorded. In terms of total abundance (number of individuals) and breeding sites, the censuses recorded 134163 birds at 44 sites in 1979, 231186 birds at 58 sites in 1989, and 279276 birds at 57 sites in 2002 (Table 8). In each of the three survey years, three species accounted for over $75 \%$ of the total seabird population-Northern Gannet, Black-legged Kittiwake, and Common Murre. Individual species accounts are as follows:

Common Eider: In 2001, the total population of breeding eiders (subspecies dresseri) in the St. Lawrence Estuary and Gulf was estimated at 42000 pairs (The Joint Working Group on the Management of the Common Eider 2004). The 2002 seabird census of the Gaspé Peninsula recorded only 235 pairs of this eider, which represents less than $1 \%$ of the total population in Québec. Nevertheless, the population is steadily increasing, from 41 pairs in 1979 to 128 pairs in 1989 to 235 pairs in 2002 (Table 8). In 2002 this seabird bred at Illot Mahy nord, Île Plate, and Pointe de Sandy Beach (Table 6). A few pairs are also believed to nest each year at the foot of the cliff on the Forillon Peninsula. 
TABLE 2. Number, name, and centroïd coordinates of sites on the Gaspé Peninsula surveyed for nesting seabirds in 1979, 1989, and 2002. (Colony numbers correspond to locations in Figure 1.)

\begin{tabular}{|c|c|c|c|}
\hline \multicolumn{2}{|c|}{ Miguasha to Îlot Mahy Sud sector } & \multicolumn{2}{|c|}{ Îlot Mahy Nord to Forillon sector } \\
\hline Colony & Coordinates $^{1}$ & Colony & Coordinates $^{1}$ \\
\hline 1. Miguasha to Saint-Omer & $48^{\circ} 04^{\prime} \mathrm{N}, 66^{\circ} 18^{\prime} \mathrm{W}$ & 29. Îlot Mahy nord & $48^{\circ} 15^{\prime} \mathrm{N}, 64^{\circ} 45^{\prime} \mathrm{W}$ \\
\hline 2. Saint-Omer & $48^{\circ} 07^{\prime} \mathrm{N}, 66^{\circ} 15^{\prime} \mathrm{W}$ & 30. Banc de la baie du Grand Pabos & $48^{\circ} 20^{\prime} \mathrm{N}, 64^{\circ} 42^{\prime} \mathrm{W}$ \\
\hline 3. Banc de Carleton & $48^{\circ} 06^{\prime} \mathrm{N}, 66^{\circ} 08^{\prime} \mathrm{W}$ & 31. Barachois de Chandler & $48^{\circ} 21^{\prime} \mathrm{N}, 64^{\circ} 41^{\prime} \mathrm{W}$ \\
\hline 4. Île au Pique-Nique & $48^{\circ} 06^{\prime} \mathrm{N}, 66^{\circ} 07^{\prime} \mathrm{W}$ & 32. Île Dupuis & $48^{\circ} 21^{\prime} \mathrm{N}, 64^{\circ} 40^{\prime} \mathrm{W}$ \\
\hline 5. Île Taylor & $48^{\circ} 09^{\prime} \mathrm{N}, 65^{\circ} 51^{\prime} \mathrm{W}$ & 33. Chandler to Grande-Rivière & $48^{\circ} 21^{\prime} \mathrm{N}, 64^{\circ} 39^{\prime} \mathrm{W}$ \\
\hline 6. New Richmond to Bonaventure & $48^{\circ} 09^{\prime} \mathrm{N}, 65^{\circ} 50^{\prime} \mathrm{W}$ & 34. Barachois de Pabos & $48^{\circ} 23^{\prime} \mathrm{N}, 64^{\circ} 35^{\prime} \mathrm{W}$ \\
\hline 7. Pointe Howatson & $48^{\circ} 08^{\prime} \mathrm{N}, 65^{\circ} 49^{\prime} \mathrm{W}$ & 35. Grande-Rivière to Cap d'Espoir & $48^{\circ} 24^{\prime} \mathrm{N}, 64^{\circ} 29^{\prime} \mathrm{W}$ \\
\hline 8. Caps Noirs & $48^{\circ} 07^{\prime} \mathrm{N}, 65^{\circ} 48^{\prime} \mathrm{W}$ & 36. Grande-Rivière & $48^{\circ} 25^{\prime} \mathrm{N}, 64^{\circ} 26^{\prime} \mathrm{W}$ \\
\hline 9. Caplan & $48^{\circ} 06^{\prime} \mathrm{N}, 65^{\circ} 39^{\prime} \mathrm{W}$ & 37. Sainte-Thérèse-de-Gaspé & $48^{\circ} 25^{\prime} \mathrm{N}, 64^{\circ} 25^{\prime} \mathrm{W}$ \\
\hline 10. Ruisseau Leblanc & $48^{\circ} 05^{\prime} \mathrm{N}, 65^{\circ} 37^{\prime} \mathrm{W}$ & 38. Cap d'Espoir to Percé & $48^{\circ} 25^{\prime} \mathrm{N}, 64^{\circ} 19^{\prime} \mathrm{W}$ \\
\hline 11. Marais de Saint-Siméon & $48^{\circ} 04^{\prime} \mathrm{N}, 65^{\circ} 33^{\prime} \mathrm{W}$ & 39. Cap d'Espoir & $48^{\circ} 26^{\prime} \mathrm{N}, 64^{\circ} 19^{\prime} \mathrm{W}$ \\
\hline 12. Bonaventure to Paspébiac & $48^{\circ} 02^{\prime} \mathrm{N}, 65^{\circ} 29^{\prime} \mathrm{W}$ & 40. Cap Malin & $48^{\circ} 27^{\prime} \mathrm{N}, 64^{\circ} 19^{\prime} \mathrm{W}$ \\
\hline 13. Îlots de la rivière Bonaventure & $48^{\circ} 03^{\prime} \mathrm{N}, 65^{\circ} 28^{\prime} \mathrm{W}$ & 41. Weygand & $48^{\circ} 29^{\prime} \mathrm{N}, 64^{\circ} 17^{\prime} \mathrm{W}$ \\
\hline 14. Paspébiac Ouest & $48^{\circ} 02^{\prime} \mathrm{N}, 65^{\circ} 17^{\prime} \mathrm{W}$ & 42. Cap Blanc & $48^{\circ} 30^{\prime} \mathrm{N}, 64^{\circ} 13^{\prime} \mathrm{W}$ \\
\hline 15. Marais de Paspébiac & $48^{\circ} 02^{\prime} \mathrm{N}, 65^{\circ} 15^{\prime} \mathrm{W}$ & 43. Bonaventure Island & $48^{\circ} 30^{\prime} \mathrm{N}, 64^{\circ} 10^{\prime} \mathrm{W}$ \\
\hline 16. Paspébiac to Shigawake & $48^{\circ} 01^{\prime} \mathrm{N}, 65^{\circ} 15^{\prime} \mathrm{W}$ & 44. Rocher Percé & $48^{\circ} 32^{\prime} \mathrm{N}, 64^{\circ} 12^{\prime} \mathrm{W}$ \\
\hline 17. Pointe aux Corbeaux & $48^{\circ} 02^{\prime} \mathrm{N}, 65^{\circ} 13^{\prime} \mathrm{W}$ & 45. Percé to Cannes de Roches & $48^{\circ} 32^{\prime} \mathrm{N}, 64^{\circ} 12^{\prime} \mathrm{W}$ \\
\hline 18. Pointe Huntington & $48^{\circ} 03^{\prime} \mathrm{N}, 65^{\circ} 11^{\prime} \mathrm{W}$ & 46. Les Trois Soeurs & $48^{\circ} 32^{\prime} \mathrm{N}, 64^{\circ} 13^{\prime} \mathrm{W}$ \\
\hline 19. Pointe à Ritchie & $48^{\circ} 03^{\prime} \mathrm{N}, 65^{\circ} 09^{\prime} \mathrm{W}$ & 47. Coin-du-Banc to Pte St-Pierre & $48^{\circ} 34^{\prime} \mathrm{N}, 64^{\circ} 18^{\prime} \mathrm{W}$ \\
\hline 20. Saint-Godefroi & $48^{\circ} 05^{\prime} \mathrm{N}, 65^{\circ} 06^{\prime} \mathrm{W}$ & 48. Barachois de Malbaie & $48^{\circ} 36^{\prime} \mathrm{N}, 64^{\circ} 18^{\prime} \mathrm{W}$ \\
\hline 21. Shigawake to Chandler & $48^{\circ} 06^{\prime} \mathrm{N}, 65^{\circ} 04^{\prime} \mathrm{W}$ & 49. Île Plate & $48^{\circ} 38^{\prime} \mathrm{N}, 64^{\circ} 09^{\prime} \mathrm{W}$ \\
\hline 22. Shigawake & $48^{\circ} 06^{\prime} \mathrm{N}, 65^{\circ} 03^{\prime} \mathrm{W}$ & 50. Pointe St-Pierre to Douglastown & $48^{\circ} 37^{\prime} \mathrm{N}, 64^{\circ} 10^{\prime} \mathrm{W}$ \\
\hline 23. Colline de Port-Daniel & $48^{\circ} 08^{\prime} \mathrm{N}, 64^{\circ} 59^{\prime} \mathrm{W}$ & 51. La Grande Anse & $48^{\circ} 41^{\prime} \mathrm{N}, 64^{\circ} 14^{\prime} \mathrm{W}$ \\
\hline 24. La Vieille (Pointe Pillar) & $48^{\circ} 11^{\prime} \mathrm{N}, 64^{\circ} 56^{\prime} \mathrm{W}$ & 52. Bois-Brûlé & $48^{\circ} 46^{\prime} \mathrm{N}, 64^{\circ} 22^{\prime} \mathrm{W}$ \\
\hline 25. Gascons-Ouest & $48^{\circ} 11^{\prime} \mathrm{N}, 64^{\circ} 53^{\prime} \mathrm{W}$ & 53. Douglastown to Sandy Beach & $48^{\circ} 46^{\prime} \mathrm{N}, 64^{\circ} 22^{\prime} \mathrm{W}$ \\
\hline 26. Pointe Reddish & $48^{\circ} 11^{\prime} \mathrm{N}, 64^{\circ} 52^{\prime} \mathrm{W}$ & 54. Cap Haldimand & $48^{\circ} 48^{\prime} \mathrm{N}, 64^{\circ} 23^{\prime} \mathrm{W}$ \\
\hline 27. Anse à Pierre Loiselle & $48^{\circ} 12^{\prime} \mathrm{N}, 64^{\circ} 49^{\prime} \mathrm{W}$ & 55. Pointe de Sandy Beach & $48^{\circ} 50^{\prime} \mathrm{N}, 64^{\circ} 24^{\prime} \mathrm{W}$ \\
\hline \multirow[t]{4}{*}{ 28. Îlot Mahy sud } & $48^{\circ} 15^{\prime} \mathrm{N}, 64^{\circ} 45^{\prime} \mathrm{W}$ & 56. Pointe Jacques Cartier (Gaspé) & $48^{\circ} 51^{\prime} \mathrm{N}, 64^{\circ} 29^{\prime} \mathrm{W}$ \\
\hline & & 57. Forillon Peninsula & $48^{\circ} 47^{\prime} \mathrm{N}, 64^{\circ} 12^{\prime} \mathrm{W}$ \\
\hline & & 58. Cloridorme to Marsoui & $49^{\circ} 11^{\prime} \mathrm{N}, 64^{\circ} 50^{\prime} \mathrm{W}$ \\
\hline & & 59. Marsoui to Baie des Capucins & $49^{\circ} 13^{\prime} \mathrm{N}, 66^{\circ} 04^{\prime} \mathrm{W}$ \\
\hline
\end{tabular}

${ }^{1}$ For shoreline sections, the coordinates of the starting locations are given.

Leach's Storm-Petrel: On the Gaspé Peninsula, this petrel has only ever been known to nest at two locations, Forillon Peninsula and Bonaventure Island. By the 1930s, the Forillon colony no longer existed (Ball 1938), leaving only the Bonaventure Island colony. This colony was probably never large-in the 1979 and 1989 censuses only 10 and 21 pairs were counted, respectively. Unfortunately, no petrels (nor active burrows) were observed in the 2002 census (Table 7). In fact, this species' breeding status in Québec is currently uncertain. Historically, it nested at several locations along the North Shore of the Gulf of St. Lawrence and on the Magdalen Islands. However, the only active colony found in the 1998-1999 census of North Shore Migratory Bird Sanctuaries (Corossol Island with 718 active burrows, Rail and Chapdelaine 2004) was deserted in the 2005 census (Rail and Cotter 2007), and no active burrow has been recorded on the Magdalen Islands in the last 20 years, although observations in 2007 of adults in the Île Brion Ecological Reserve during a survey for this species suggest a small colony still exists there (CWS, unpublished data). In some cases, including Bonaventure Island, the presence of Red Foxes (Vulpes vulpes) might be responsible of the abandonment of the colony.

Northern Gannet: On the Gaspé Peninsula, this species nests only on Bonaventure Island. During the last census the Northern Gannet was the most abundant of all seabirds with an estimated 53635 pairs (Table 8). Since 1979 this gannet colony has grown at a fairly consistent rate; the compound annual growth rate (CAGR) was $2.8 \%$ between 1979 and 1989 and 5.5\% between 1989 and 2004 (Table 8). This colony was also censused in 1999 and was estimated at 36936 pairs; the CAGR for 1999 to 2004 was 7.7\%. In 1999 and 2004 the colony showed no sign of density-dependant effects, and because breeding success estimates obtained in 1999 and 2004 were high and stable (CWS, unpublished data), we think that the colony should continue to increase in the next few years.

Double-crested Cormorant: After a doubling in population size between 1979 and 1989, the size of this cormorant's population on the Gaspé Peninsula did not change substantially between 1989 and 2002 (CAGR of only $0.4 \%$ ), reaching 4889 pairs in 2002 (Table 8). A stabilization in populations between the mid-1980s 


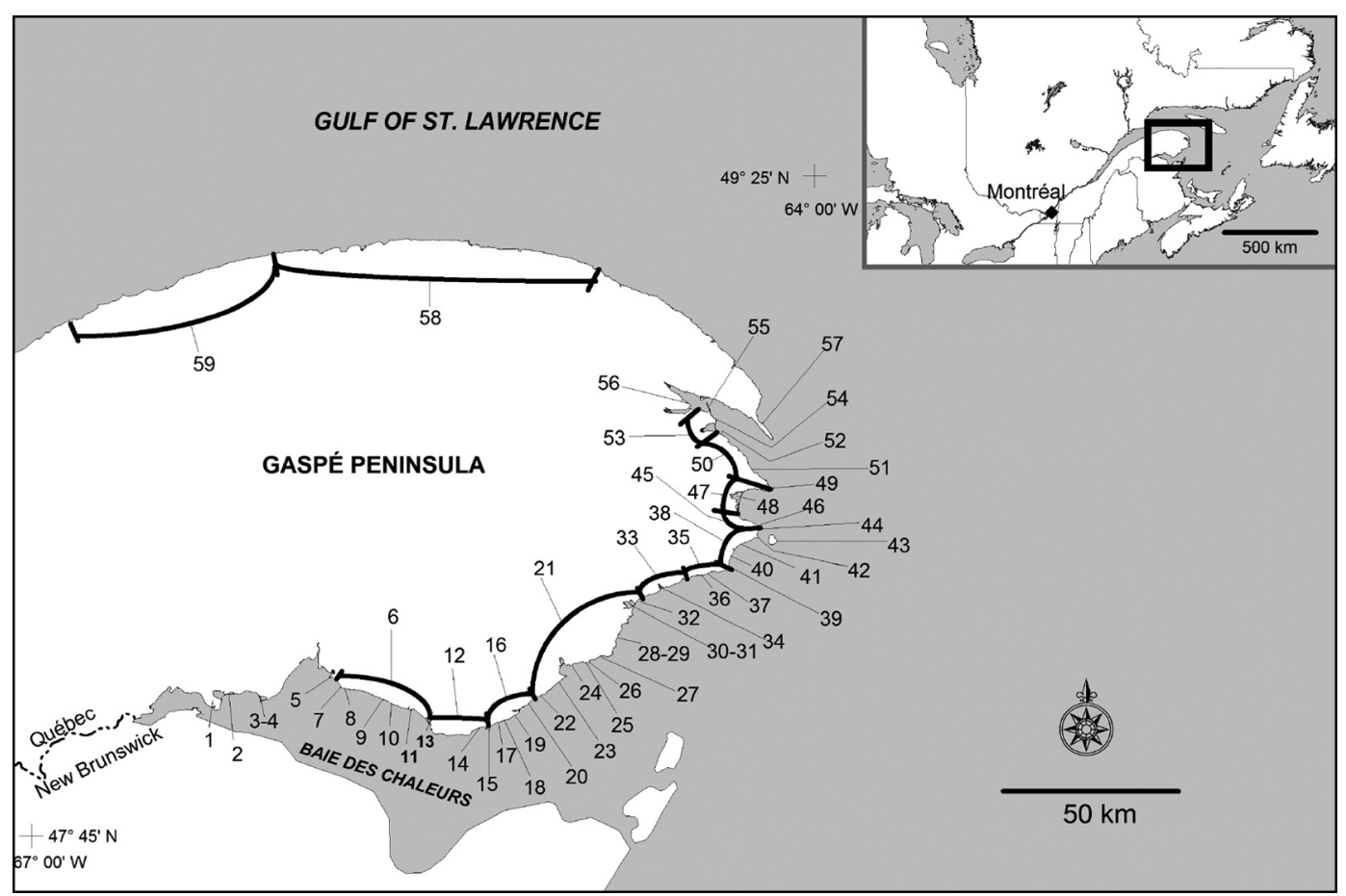

FIGURE 1. Location of colonies and shoreline sectors on the Gaspé Peninsula surveyed for breeding seabirds in 2002. See Table 2 for location listings and coordinates.

and the early 2000s has also been recorded in Nova Scotia (Boyne and Beukens 2004) and New Brunswick (Boyne and Hudson 2002). In Québec, the population on the Magdalen Islands also remained fairly stable between 1990 and 2002 (CWS, unpublished data), as did the overall population in breeding colonies within the Migratory Bird Sanctuaries along the St. Lawrence North Shore between 1993 and 2005 (Rail and Cotter 2007). Interestingly, the increase in the size of the Gaspé population between 1979 and 1989 was accompanied with an additional nine new colonies in 1989, bringing to a total of 29 active colonies that year. In 2002 , however, there was a contraction in the number of sites where it nested, as it was recorded at only 25 sites (Tables 4, 6, 7). Of the nine new colonies in 1989 , three were not active in 2002. Additionally, six colonies that were active in both 1979 and 1989 harboured no cormorants in 2002. The loss of these nine colonies was offset by five new colonies, including one comprising 393 pairs in the New RichmondBonaventure region and, interestingly, a small colony on Bonaventure Island. As Chapdelaine and Brousseau (1992) stated, the majority of Double-crested Cormorant colonies on the Gaspé Peninsula are found on sea-cliffs that in some areas are unstable and subject to erosion. Thus it is not surprising that between censuses with an interval of $\geq 10$ years there are colonies that become inactive and new ones are created.
Great Cormorant: World-wide this species has the largest breeding distribution of all cormorant species, but only a small fraction of its population nests in North America (Hatch et al. 2000). In Québec there are approximately 20 small colonies (total population $<1500$ pairs) (CWS, unpublished data), with historically only one colony on the Gaspé Peninsula at Rocher Percé. In 1979 this colony had 16 nesting pairs, and in the 1989 census this number had doubled to 35 pairs. This upward trend continued in the 1990s as the total Gaspé population reached 96 pairs in 2002 (Table 7). In that census, the Rocher Percé colony had changed little in size since 1989, but a new and fairly large colony of 50 pairs was found at Cap d'Espoir (Table 7). Small numbers (1-3 pairs) were also observed at four other sites in 2002 (Tables 4, 6), which along with the new colony at Cap d'Espoir may indicate the population is expanding not only in size but also in its distribution. Rail and Chapdelaine (2004) also reported on the recent appearance of small Great Cormorant colonies in North Shore Migratory Bird Sanctuaries, although the most recent survey of these sanctuaries, in 2005 , recorded only 48 Great Cormorants, a sharp decrease from the previous survey in 1998-1999 when 342 adults were counted (Rail and Cotter 2007).

Ring-billed Gull: This gull, whose first breeding record in the Maritime Provinces was in 1965 (Lock 1988), is also a newcomer to the Gaspé Peninsula. It 
was absent during the 1979 census, and in 1989 only 21 pairs were counted at two sites, Barachois de Chandler and Pointe de Sandy Beach (Table 5). In the 2002 census, however, there was only one colony and it was not at either of those two sites. Instead it was at Saint-Omer, and the colony was surprisingly quite large with 1663 pairs (Table 3). There were more Ring-bills at this site than the traditional species that nest there, that is Herring and Great Black-backed gulls and Common Terns. With numbers of Ring-billed Gulls still rising in the Maritimes (Boyne and Hudson 2002; Boyne et al. 2006) and apparently also on the North Shore (Roberge 2004), it is not surprising to observe the same trend around the Gaspé Peninsula.

Herring Gull: Among all seabirds on the Gaspé Peninsula, the Herring Gull is the only species whose population declined in size between 1979 and 1989 and again between 1989 and 2002 (Table 8). From 1979 to 1989 its CAGR was $-1.8 \%$, and this rate of decline doubled to $-3.5 \%$ between 1989 and 2002. Between 1979 and 2002, the total population declined from 9796 to 5134 pairs. This decline is attributable to colonies decreasing in size as opposed to a reduction in the number of breeding sites (24 in 1979 vs 29 in 2002; Table 8). In 2002, 22 of the 29 colonies had fewer gulls than in 1989. There were, however, four colonies/sectors that increased in size by more than 50\% between 1989 and 2002: Saint-Omer, Île Taylor, Marais de Paspébiac, and the New Richmond to Bonaventure sector (Tables 3, 5). These four areas along with Îlot Mahy sud and Pointe de Sandy Beach comprised $64 \%$ of the total Herring Gull population on the Gaspé Peninsula in 2002. The decline in colony size is probably not a result of competition, such as for nest or foraging areas, with other larids. Among the 22 sites where the population declined between 1989 and 2002, there were only two-Îlot Mahy sud and Île Plate-that had a sizable increase in the population of another seabird, and at both sites it was of Great Black-backed Gulls (three other sites had smaller increases in their Great Black-backed Gull populations; Tables 3, 5). Along coastal New England, however, the more aggressive Great Black-backed Gulls have displaced Herring Gulls from certain good breeding sites, and Rome and Ellis (2004) found evidence there that Great Black-backed Gulls may suppress foraging by Herring Gulls. Elsewhere in Canada, populations of Herring Gulls have also declined in Newfoundland (Robertson et al. 2004), New Brunswick (Boyne and Hudson 2002), Nova Scotia (Boyne and Beukens 2004), and Prince Edward Island (Boyne and McKnight 2005). Chapdelaine and Rail (1997) showed that there was a positive relationship between Herring Gull populations in the North Shore sanctuaries and cod fishery activities in the Gulf of St. Lawrence, the latter providing substantial amounts of fish offal and discards to breeding gulls. After a thriving period that lasted up to the end of the 1980s, the cod fishery collapsed, a situation which probably trig- gered the decline of the Herring Gull populations on the North Shore (-70\% between 1988 and 1993; Chapdelaine 1995) and around the Gaspé Peninsula as well (-37\% between 1989 and 2002). We think that the disappearance of this abundant anthropogenic food source brought Herring Gull populations back to a more "natural" level, which will stabilize in the future, as has been observed in North Shore sanctuaries since the early 1990s (Rail and Cotter 2007).

Great Black-backed Gull: This large gull often nests in mixed colonies with its more abundant relative, the Herring Gull. Unlike that species, however, Great Black-backs increased dramatically in numbers on the Gaspé Peninsula between 1979 and 1989, with a CAGR of $23.7 \%$. After reaching a population of 1337 pairs in 1989, the population in 2002 was relatively unchanged with 1322 pairs. The large increase from 1979 to 1989 was due in part to colonies increasing in size but also to a doubling in the number of colonies (Table 8). Comparing 2002 with 1989, there were a few changes in colony locations. In 2002 this gull did not nest at Barachois de Chandler but colonized the Banc de la baie du Grand Pabos in the adjacent bay, less than $1 \mathrm{~km}$ away. It also deserted the cliffs from Paspébiac to Shigawake, but became established between New Richmond and Bonaventure. Elsewhere, in each of the neighbouring Maritime Provinces Great Black-backed Gull numbers declined between the late 1980s and early 2000s (Boyne and Beukens 2004; Boyne and Hudson 2002; Boyne and McKnight 2005). In the Migratory Bird Sanctuaries (excluding Gros Mécatina and Saint-Augustin) along the St. Lawrence North Shore, however, the population has been relatively stable, with 1883 individuals counted in 1988 and 1835 individuals counted in 2005 (Rail and Chapdelaine 2004; Rail and Cotter 2007).

Black-legged Kittiwake: This small larid was the most abundant seabird species in both 1979 and 1989 (Table 8). The size of the kittiwake population on the Gaspé Peninsula doubled in size in the 1980s, from 21827 pairs in 1979 to 43423 pairs in 1989. This species' distribution and abundance between 1974 and 1985 have been described in detail for the entire Gulf of St. Lawrence by Chapdelaine and Brousseau (1989). In the 1990s, the population stopped growing, and in 2002 there were 13\% fewer pairs (37 649) than there were in 1989. Recent downward trends (i.e., negative annual growth rates) have been observed in other regions of eastern Canada: Magdalen Islands (Québec), -1.0\%/year, 1989-2000; Anticosti Island (Québec), -2.3\%/year, 1985-2004; North Shore Migratory Bird Sanctuaries (Québec), -8.0\%, 1988 to 19981999 but followed by a stabilization with a rate of 0.64\%, 1998-1999 to 2005; Gull Island (Newfoundland), $-2.2 \%, 1971-2001$; Great Island (Newfoundland), -9.9\%, 1994-2003; and Baccalieu Island (Newfoundland), $-3.6 \%, 1984-2003$ (CWS, unpublished data; Rail and Cotter 2007; Robertson et al. 2004; G. Robertson, personal communication). In each of the 


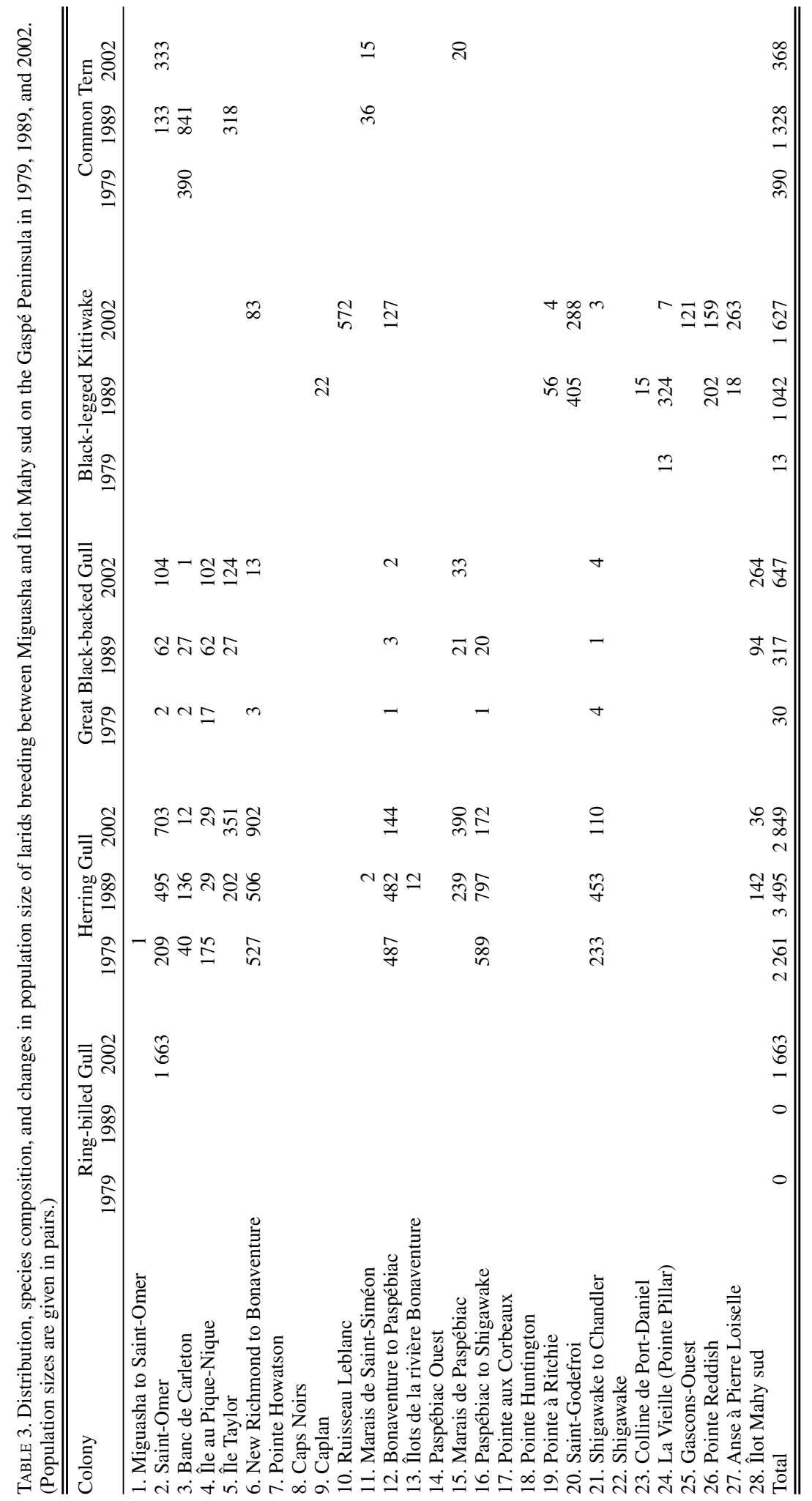




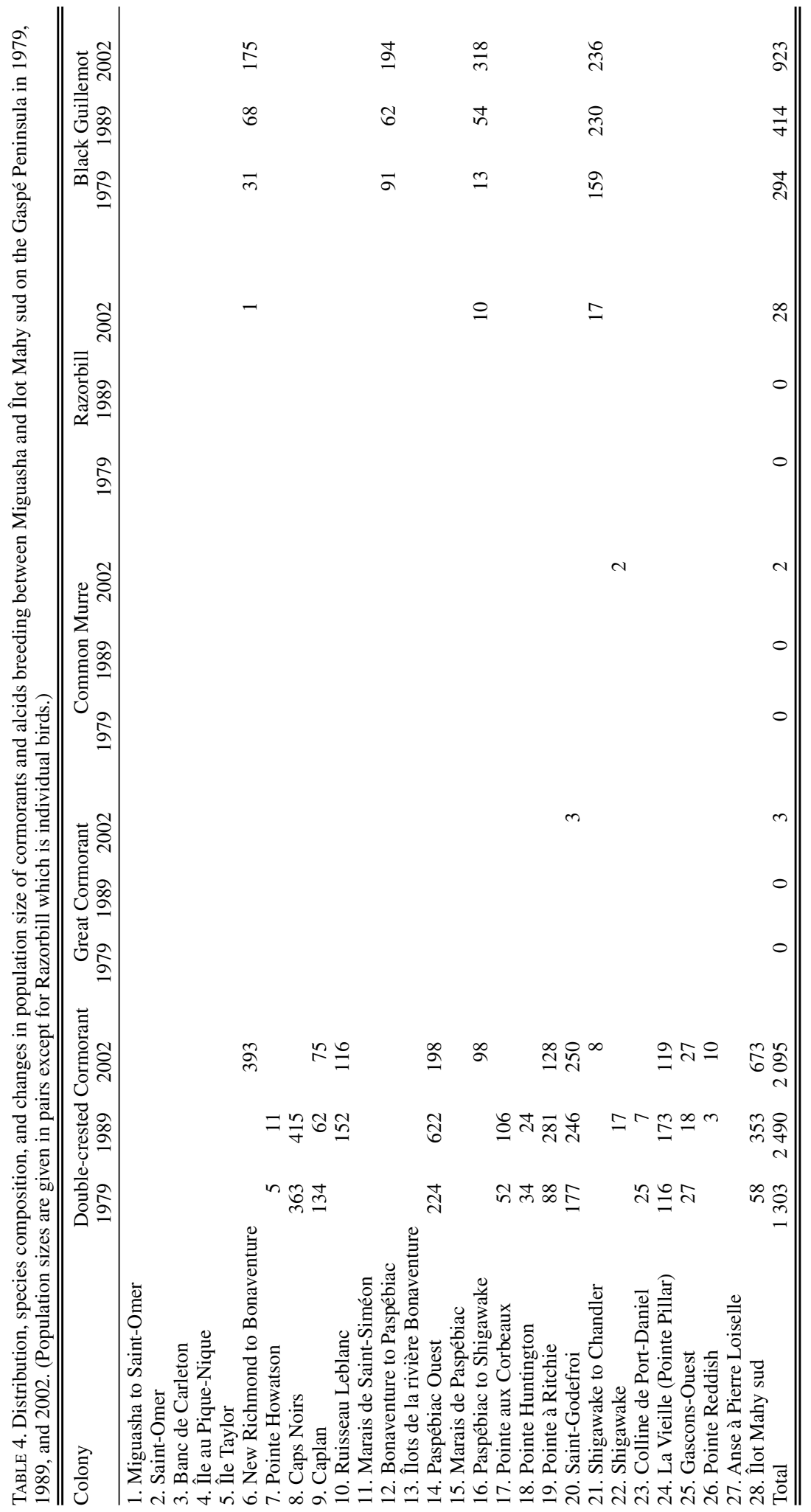




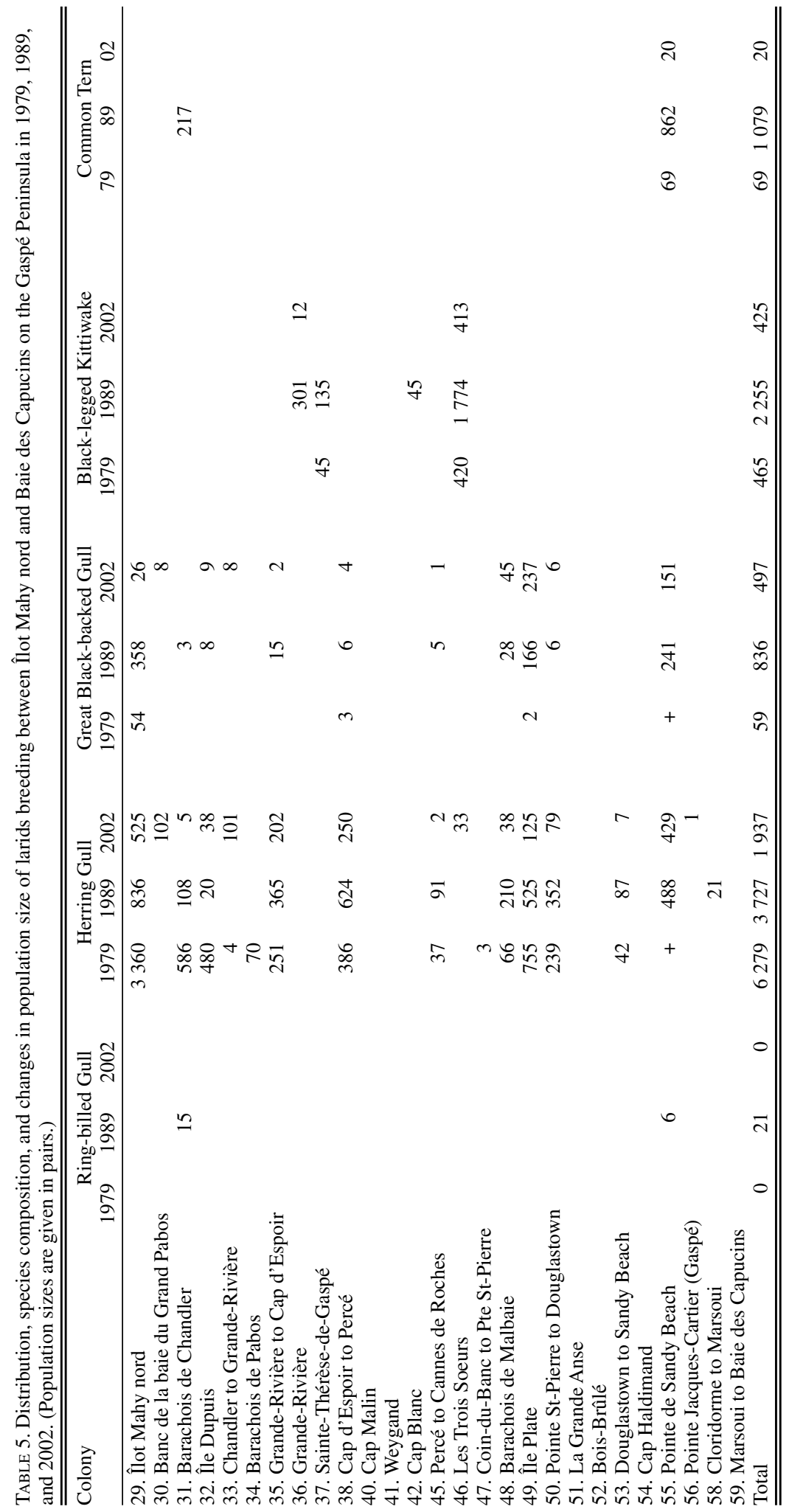




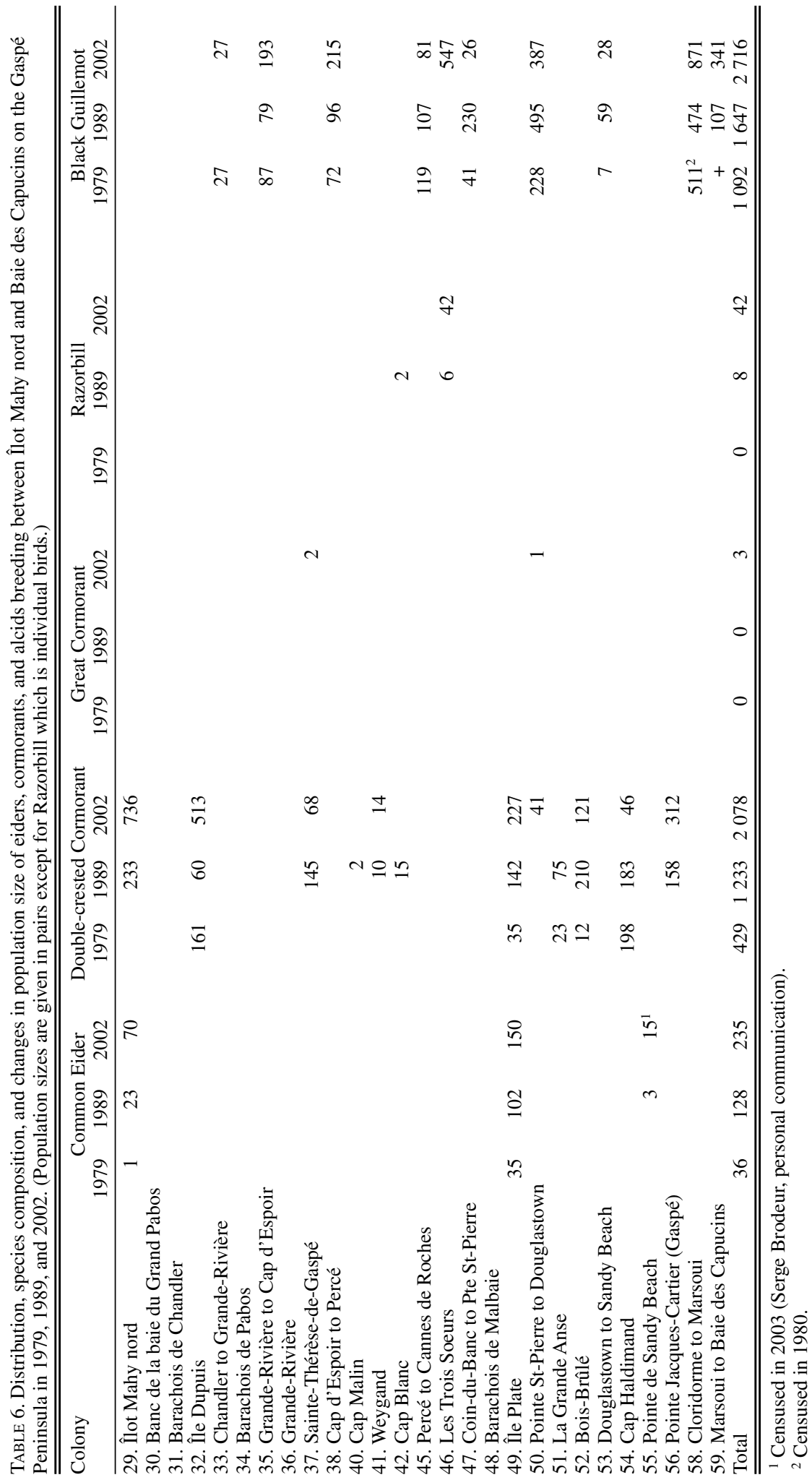




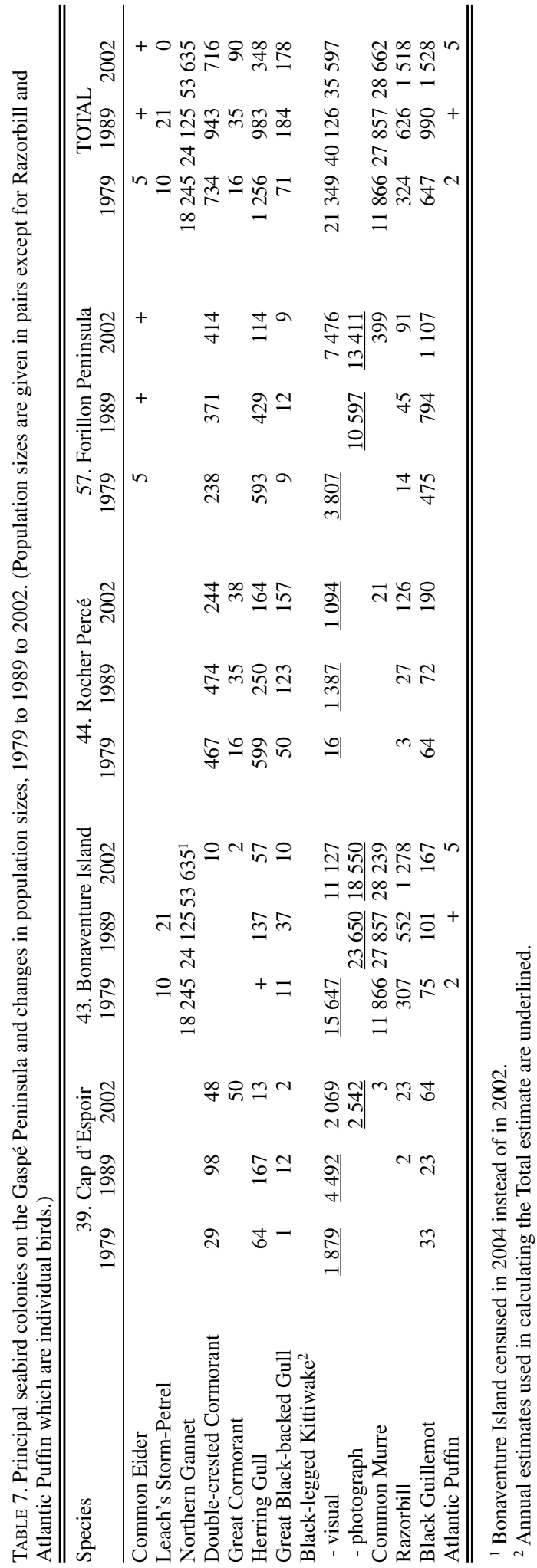

three Gaspé Peninsula censuses, five colonies comprised $\geq 95 \%$ of the total kittiwake population: Cap d'Espoir, Bonaventure Island, Les Trois Soeurs, Rocher Percé, and Forillon Peninsula (Tables 5, 7). Comparing colony sizes in 2002 with 1979 , the former three colonies had changed by less than $\pm 35 \%$, whereas the latter two had increased substantially in size, in particular Rocher Percé, which increased from 16 pairs in 1979 to 1094 pairs in 2002 (Table 7). In each of the three censuses, the Bonaventure Island colony harboured the most kittiwakes, with an estimated 18 550 pairs nesting in 2002. After the 1989 census, at which time there were 23650 pairs at this colony, Chapdelaine and Brousseau (1992) postulated that the Bonaventure Island colony may have reached its peak due to a lack of available nesting habitat.

Common Tern: Of all species censused in 1979, 1989, and 2002, the Common Tern had the greatest change in CAGR over the 1989 to 2002 period as compared with 1979 to 1989 (Table 8). In that first interval, the population increased at an annual rate of $18.0 \%$, from 459 pairs in 1979 to 2407 in 1989. From 1989 to 2002, however, the tern population declined at a CAGR of $-13.1 \%$. The 2002 population was estimated at only 388 pairs, which is fewer birds than there were in 1979 (Table 8); only one other species, the Leach's Storm-Petrel, had a smaller population in 2002 than in 1979. Terns have never nested at a large number of sites on the Gaspé Peninsula. In 1979 the Common Tern nested only at Banc de Carleton and Pointe de Sandy Beach, and both of these colonies had increased considerably in size by 1989 and were the largest of all tern colonies, with each containing over 800 pairs (Tables 3, 5). In addition to these two colonies, there were four new colonies in 1989, and among these six colonies four had 200 or more nesting pairs. In 2002, however, there were only four colonies, of which three consisted of 20 or fewer pairs. During this census there were no terns at Banc de Carleton and only 20 pairs at Pointe de Sandy Beach. The only bright spot for this species was the colony at Saint-Omer, which was a new colony in 1989. In that year this colony consisted of 133 pairs, which increased to 333 pairs in 2002. Elsewhere in Québec, tern numbers on the Magdalen Islands were quite stable between 1990 and 2000 at around 2600 pairs (CWS, unpublished data), and in the Mingan Archipelago National Park Reserve, on the North Shore of the Gulf of St. Lawrence, numbers have been increasing in the last 20 years, with more than four thousand pairs in 1999 (Roberge 2004). In neighbouring New Brunswick, the number of Common Terns along the Gulf of St. Lawrence coast has been relatively stable, with a small decline between 1983 (15 500 pairs) and 2000 (12 618 pairs) and then a small increase in 2005 (13 283 pairs) (Boyne et al. 2006). The situation on Prince Edward Island over this same period has been more drastic, as the island's population fell from 
TABLE 8. Total population sizes of seabirds breeding on the Gaspé Peninsula in 1979, 1989, and 2002 and the compound annual growth rates (CAGR) between each census year. (Population sizes are given in pairs except for Razorbill and Atlantic Puffin which are individual birds.)

\begin{tabular}{|c|c|c|c|c|c|c|c|c|}
\hline \multirow[b]{2}{*}{ Species } & \multicolumn{2}{|c|}{1979} & \multicolumn{2}{|c|}{1989} & \multirow{2}{*}{$\begin{array}{c}\text { CAGR } \\
1979-1989\end{array}$} & \multicolumn{2}{|c|}{2002} & \multirow{2}{*}{$\begin{array}{c}\text { CAGR } \\
1989-2002\end{array}$} \\
\hline & Population & $\begin{array}{l}\text { Number } \\
\text { of colonies }\end{array}$ & Population & $\begin{array}{l}\text { Number } \\
\text { of colonies }\end{array}$ & & Population & $\begin{array}{l}\text { Number } \\
\text { of colonies }\end{array}$ & \\
\hline Common Eider & 41 & 3 & 128 & 3 & $12.1 \%$ & 235 & 3 & $4.8 \%$ \\
\hline Leach's Storm-Petrel & 10 & 1 & 21 & 1 & $7.7 \%$ & 0 & 0 & \\
\hline Northern Gannet & 18245 & 1 & 24125 & 1 & $2.8 \%$ & $53635^{1}$ & 1 & $5.5 \%$ \\
\hline Double-crested Cormorant & 2466 & 20 & 4666 & 29 & $6.6 \%$ & 4889 & 25 & $0.4 \%$ \\
\hline Great Cormorant & 16 & 1 & 35 & 1 & $8.1 \%$ & 96 & 6 & $8.1 \%$ \\
\hline Ring-billed Gull & 0 & 0 & 21 & 2 & & 1663 & 1 & $40.0 \%$ \\
\hline Herring Gull & 9796 & 24 & 8205 & 28 & $-1.8 \%$ & 5134 & 29 & $-3.5 \%$ \\
\hline Great Black-backed Gull & 160 & 14 & 1337 & 23 & $23.7 \%$ & 1322 & 24 & $-0.1 \%$ \\
\hline Black-legged Kittiwake & 21827 & 7 & 43423 & 15 & $7.1 \%$ & 37649 & 16 & $-1.1 \%$ \\
\hline Common Tern & 459 & 2 & 2407 & 6 & $18.0 \%$ & 388 & 4 & $-13.1 \%$ \\
\hline Common Murre & 11866 & 1 & 27857 & 1 & $8.9 \%$ & 28664 & 5 & $0.2 \%$ \\
\hline Razorbill & 324 & 3 & 634 & 6 & $6.9 \%$ & 1588 & 8 & $7.3 \%$ \\
\hline Black Guillemot & 2033 & 16 & 3051 & 16 & $4.1 \%$ & 5167 & 18 & $4.1 \%$ \\
\hline Atlantic Puffin & 2 & 1 & + & 1 & & 5 & 1 & \\
\hline Total (individuals) & 134163 & & 231186 & & $5.6 \%$ & 279276 & & $1.5 \%$ \\
\hline
\end{tabular}

${ }^{1}$ Censused in 2004.

approximately 3000 pairs in 1984 to 738 pairs in 2004 (Boyne and McKnight 2005).

Common Murre: Of the three most abundant seabirds, the Common Murre showed the strongest growth in population between 1979 and 1989 with a CAGR of $8.9 \%$ (Table 8 ). The population more than doubled in size between those two censuses, from 11866 pairs in 1979 to 27857 in 1989 . From 1989 until the next census in 2002, however, the population increased only marginally to 28664 pairs (CAGR of $0.2 \%$ ) (Table 8). Across the Gulf of St. Lawrence, in the Migratory Bird Sanctuaries of the North Shore, between 1977 and 1988 annual growth was approximately 9\% (Chapdelaine and Brousseau 1991) but between 1988 and 1998-1999 the population stabilized and the annual growth was $<1.5 \%$ (Rail and Chapdelaine 2004). This was followed, however, by a $50 \%$ decline in the total murre population in the sanctuaries between 19981999 and 2005 (CAGR of -11.8\%) (Rail and Cotter 2007). In both 1979 and 1989 there was only one murre colony on the Gaspé Peninsula, and that was on Bonaventure Island. In 2002 this colony was about the same size as it was in 1989 with 28239 pairs (Table 7). There were, however, three new small colonies in 2002: Cap d'Espoir, Rocher Percé, and Forillon Peninsula (Table 7). Of these three new sites, Forillon contained the largest number of murres with an estimated 399 pairs.

Razorbill: Whereas the population of Common Murres increased considerably in size between 1979 and 1989 but then stablized, the population of this alcid doubled in size between each census. With 324 individuals in 1979, the Razorbill population increased to 634 in 1989 (CAGR of $6.9 \%$ ) and then to 1588 in 2002 (CAGR of $7.3 \%$ ) (Table 8). In all three censuses Razorbills were recorded at Bonaventure Island, Rocher Percé, and Forillon (Table 7). In 1989 and 2002 they also nested at Les Trois Soeurs and Cap d'Espoir
(Tables 6, 7), and in 2002 three new small colonies were discovered, for a total of eight colonies that year. The Bonaventure Island colony accounts for $\geq 80 \%$ of the total Razorbill population on the Gaspé Peninsula. This percentage, however, has been declining, from $97 \%$ in 1979 to $87 \%$ in 1989 to $80 \%$ in 2002 , despite the fact that this colony grew from only 307 birds in 1979 to 1278 in 2002. As observed with many other species, the population of Razorbills along the St. Lawrence North Shore has shown a similar trend with the Gaspé population. In Migratory Bird Sanctuaries surveyed in that region at 5-6 year intervals, this alcid had annual growth of $8.6 \%$ and $7.3 \%$ for 1993 to 1998 1999 and 1998-1999 to 2005, respectively (Rail and Cotter 2007). In the St. Lawrence Estuary, the size and number of colonies have also been growing over the past 20 years (CWS, unpublished data).

Black Guillemot: The population of Black Guillemots on the Gaspé Peninsula has exhibited a consistent upward trend since 1979 , with a CAGR of $4.1 \%$ for both 1979 to 1989 and 1989 to 2002 periods (Table $8)$. With such a rate of increase, this population has more than doubled in size between 1979 (2 033 pairs) and 2002 (5 167 pairs). The number of shoreline sectors where this alcid has been recorded during each of the three censuses has changed very little. In both 1979 and 1989 it was recorded at 16 sites, and this increased to 18 in 2002 (Table 8). For the first time, in 2002 a good-sized colony of guillemots was observed at Les Trois Soeurs. With 547 pairs, only Forillon Peninsula and the long stretch of coastline from Cloridorme to Marsoui harboured more guillemots. This little seabird is also doing well in the Migratory Bird Sanctuaries of the St. Lawrence North Shore, where the population has increased from 411 birds in 1993 to 924 birds in 2005 (Rail and Cotter 2007). 
Atlantic Puffin: With the possible exception of the Leach's Storm-Petrel, this species is the least common of all seabirds on the Gaspé Peninsula. It is known to nest only on Bonaventure Island, where "a few pairs breed on the cliffs amid thousands of Northern Gannets and Common Murres" (Chapdelaine 1996). Breeding sites, probably hidden at the deep end of cliff ledges, cannot be counted, but small numbers ( $\leq 5$ birds) of puffins were seen during each of the three censuses (Table 7).

\section{Discussion}

The first systematic seabird survey of the Gaspé Peninsula in 1979 recorded a population of approximately 134000 birds. Over the next 10 years this population increased by $72 \%$ to just over 231000 birds. During that decade, large increases in seabird numbers were also observed along the North Shore of the Gulf of St. Lawrence. Migratory Bird Sanctuaries in that region are censused every 5-6 years, and seabird populations within those sanctuaries increased by $65 \%$ between 1977 and 1982 (Chapdelaine and Brousseau 1984) and by $46 \%$ between 1982 and 1988 (Chapdelaine and Brousseau 1991). For both the Gaspé and the North Shore, the large increases in seabird populations in the 1980s may be attributed to increases in forage fish such as sandlance (Ammodytes spp.) and Capelin (Mallotus villosus) in the waters of the Estuary and Gulf of St. Lawrence, and the increase in the supply of forage fish may have occurred because of the decline in Cod (Gadus morhua) and other predator fish species due to overfishing (Chapdelaine and Brousseau 1991, 1992). Also, the decrease in some fishery activities may have resulted in reduced mortality of birds getting entangled in fishing gear. Finally, the consumption of seabirds and their eggs, often illegal, is probably a declining habit in local communities.

In the 1990s on the Gaspé Peninsula, however, the strong growth in the seabird population that occurred in the previous decade had slowed. Over the 13 years between the 1989 and 2002 censuses, the total population increased by only $21 \%$ to approximately 279000 birds (Table 8). Similarly, seabird populations in Migratory Bird Sanctuaries along the St. Lawrence North Shore, which grew strongly in the 1980s, did not fare as well in the 1990s and early 2000s. In eight sanctuaries that were censused in 1988 and again in 2005, the total seabird population actually declined by $7 \%$ during that period (Chapdelaine and Brousseau 1991; Rail and Cotter 2007).

While most seabird species (11 of 14) on the Gaspé Peninsula exhibited similar trends between 1979 and 1989 , that is, increases of $>30 \%$, this was not the situation between 1989 and 2002. Over this period, six of 14 species increased in population by $\geq 70 \%$, three species decreased in numbers by $>35 \%$, and the populations of five remained relatively stable with changes of $<15 \%$. The latter group includes the Atlantic Puffin, for whom numbers are too low to assess changes in population size (Table 8).
In each of the 1979, 1989, and 2002 censuses, three species-Northern Gannet, Black-legged Kittiwake, and Common Murre-accounted for over $75 \%$ of the total population, and therefore changes in the populations of these species had the main impact on overall seabird population trends. Interestingly, between 1989 and 2002 these three species each exhibited a different trend; the population of the Northern Gannet increased by $122 \%$, that of the Black-legged Kittiwake decreased by $13 \%$, while the population of the Common Murre remained stable (increase of only $3 \%$ ).

Of the different seabird groups, between 1989 and 2002 the total population of larids declined whereas the populations of alcids and cormorants increased. Three of the five larid species that breed on the Gaspé Peninsula declined sharply ( $>35 \%$ ), whereas populations of all alcid and cormorant species either remained stable or increased. Of the remaining three individual species, Common Eiders and Northern Gannets increased in numbers, whereas the small population of Leach's Storm-Petrels declined (there were no active burrows found in 2002). Rail and Chapdelaine (2004) reported a similar pattern in the overall trends of seabirds along the St. Lawrence North Shore between 1993 and 1998-1999. Over that interval, they reported increases in population for four species, decreases for four species, and stable or moderate trends for the remaining species. As we observed on the Gaspé Peninsula in the 1990s, larids along the North Shore declined in numbers whereas populations of alcids and cormorants increased. It should be noted that among larids, the Ring-billed Gull was an exception to the downward trend; it increased considerably in numbers in both regions, with annual growth of 31.0\% (1993 to 1998-1999) and 40.0\% (1989-2002) for the North Shore sanctuaries (Rail and Chapdelaine 2004) and the Gaspé Peninsula, respectively. The coastlines of both regions are fronted by the Estuary and Gulf of St. Lawrence, which breeding seabirds of both regions use almost exclusively as their foraging grounds. It is not surprising, therefore, that the seabird populations of both regions show similar trends. Strong growth of Ring-bill populations also occurred in the Maritime Provinces, where the population grew at an annual rate of 20.9\% between 1972 and 1986 (Lock 1988), and recent censuses in Prince Edward Island (Boyne and McKnight 2005) and New Brunswick (Boyne et al. 2006) have shown that populations in these two provinces have continued to grow.

An interesting observation from our results is the 1989-2002 trend for species that are "surface feeders" as compared with those that are "divers". The proportion of the total seabird population made up of divers increased from $50 \%$ in 1989 to $70 \%$ in 2002 , and conversely the proportion for surface feeders fell from $50 \%$ to $30 \%$. A similar pattern has occurred with seabird populations on the Magdalen Islands. In this archipelago, between 1989-1990 and 2000-2002 divers increased by $20 \%$ while surface feeders declined by $20 \%$ (CWS, unpublished data). This trend seems gen- 
eralized throughout the Gulf of St. Lawrence, as within Migratory Bird Sanctuaries of the North Shore the same $20 \%$ increase in the proportion of diving species (and 20\% decrease of surface feeders) can be noted between 1988 and 2005 (CWS, unpublished data).

For the Gaspé Peninsula, the recent declines in larids, in particular among kittiwakes and terns, as well as the possible extirpation of the Leach's Storm-Petrel, are major concerns for seabird biologists and managers. Factors that may be responsible for the declines, specifically possible changes in productivity, breeding conditions, predators, and/or survival, should be studied. Despite concern for these species, the overall population trends of seabirds along this peninsula are encouraging. The total number of seabirds has doubled between the first comprehensive survey in 1979 and the most recent survey in 2002, with nine of the 14 breeding seabirds showing strong population growth over that period.

\section{Acknowledgments}

We extend special thanks to our recently retired colleague, Gilles Chapdelaine, who in addition to having organized and carried out the field work for this third seabird census of the Gaspé Peninsula is largely responsible for the development in Québec of a modern seabird monitoring program. We also thank JeanFrançois Cloutier, personnel from the Parc national de l'Île-Bonaventure-et-du-Rocher-Percé and Forillon National Park of Canada, and Serge Brodeur for their assistance in the surveys. John Chardine was of great assistance with the gannet survey.

\section{Literature Cited}

Ball, S. C. 1938. Summer birds of the Forillon, Gaspé County, Québec. Canadian Field-Naturalist 52(7): 95103, 52(8): 120-122.

Boyne, A. W., and J. T. Beukens. 2004. Census of gulls and other seabirds along the coast of mainland Nova Scotia 2002. Canadian Wildlife Service Technical Report Series Number 409, Atlantic Region. 22 pages.

Boyne, A. W., and J. K. Hudson. 2002. Census of terns and other colonial waterbirds along the Gulf of St. Lawrence coast of New Brunswick - 2000. Canadian Wildlife Service Technical Report Series Number 397, Atlantic Region. 29 pages.

Boyne, A. W., and J. McKnight. 2005. Census of terns and gulls in Prince Edward Island - 2004. Canadian Wildlife Service Technical Report Series Number 428, Atlantic Region. 29 pages.

Boyne, A. W., B. E. Toms, and J. McKnight. 2006. Census of terns and other colonial waterbirds along the Gulf of St. Lawrence coast of New Brunswick - 2005. Canadian Wildlife Service Technical Report Series Number 467, Atlantic Region. 31 pages.

Cairns, D. 1979. Censusing hole-nesting Auks by visual counts. Bird-Banding 50: 358-364.

Chapdelaine, G. 1995. Fourteenth census of seabird populations in the sanctuaries of the North Shore of the Gulf of St. Lawrence, 1993. Canadian Field-Naturalist 109: 220-226.
Chapdelaine, G. 1996. Atlantic Puffin. Pages 566-569 in The Breeding Birds of Québec: Atlas of the Breeding Birds of Southern Québec. Edited by J. Gauthier and Y. Aubry. Association québécoise des groupes d'ornithologues, Province of Quebec Society for the Protection of Birds, Canadian Wildlife Service, Environment Canada, Québec Region, Montreal. 1302 pages.

Chapdelaine, G., and P. Brousseau. 1984. Douzième inventaire des populations d'oiseaux marins dans les refuges de la Côte-Nord du golfe du Saint-Laurent. Canadian FieldNaturalist 98: 178-183.

Chapdelaine, G., and P. Brousseau. 1989. Size and trends of Black-legged Kittiwake (Rissa tridactyla) populations in the Gulf of St. Lawrence (Quebec) 1974-1985. American Birds 43: 21-24.

Chapdelaine, G., and P. Brousseau. 1991. Thirteenth census of seabird populations in the sanctuaries of the North Shore of the Gulf of St. Lawrence, 1982-1988. Canadian Field-Naturalist 105: 60-66.

Chapdelaine, G., and P. Brousseau. 1992. Distribution, abundance, and changes of seabird populations of the Gaspé Peninsula, Québec, 1979 to 1989. Canadian FieldNaturalist 106: 427-434.

Chapdelaine, G., and J.-F. Rail. 1997. Relationship between cod fishery activities and the population of Herring Gulls on the North Shore of the Gulf of St Lawrence, Québec, Canada. ICES Journal of Marine Science 54: 708-713.

Hatch, J. J., K. M. Brown, G. G. Hogan, and R. D. Morris. 2000. Great Cormorant (Phalacrocorax carbo). In The Birds of North America, Number 553. Edited by A. Poole and F. Gill. The Birds of North America, Inc., Philadelphia, Pennsylvania.

The Joint Working Group on the Management of the Common Eider. 2004. Québec Management Plan for the Common Eider Somateria mollissima dresseri. A special publication of the Joint Working Group on the Management of the Common Eider, Québec. 44 pages.

Lock, A. R. 1988. Recent increases in the breeding population of Ring-billed Gulls, Larus delawarensis, in Atlantic Canada. Canadian Field-Naturalist 102: 627-633.

Rail, J.-F., and G. Chapdelaine. 2004. Fifteenth census of seabird populations in the sanctuaries of the North Shore of the Gulf of St. Lawrence, 1998-1999. Canadian FieldNaturalist 118: 256-263.

Rail, J.-F., and R. Cotter. 2007. Sixteenth census of seabird populations in the sanctuaries of the North Shore of the Gulf of St. Lawrence, 2005. Canadian Field-Naturalist 121: $287-294$.

Roberge, B. 2004. Plan de gestion de l'avifaune marine et aquatique. Réserve de parc national du Canada de l'Archipel-de-Mingan. Volume 2: Atlas de l'avifaune marine et aquatique. Parks Canada, Mingan Field Unit. 106 pages.

Robertson, G. J., S. I. Wilhelm, and P. A. Taylor. 2004. Population size and trends of seabirds nesting on Gull and Great Islands, Witless Bay Ecological Reserve, Newfoundland, up to 2003. Canadian Wildlife Service Technical Report Series Number 418, Atlantic Region. 45 pages.

Rome, M. S., and J. C. Ellis. 2004. Foraging ecology and interactions between Herring Gulls and Great Blackbacked Gulls in New England. Waterbirds 27: 200-210.

Received 12 January 2007

Accepted 22 May 2008 